\title{
Binding of Griffonia simplicifolia I lectin to rat pulmonary alveolar macrophages and its use in purifying type II alveolar epithelial cells
}

\author{
Richard H. Simon a**, J. Philip McCoy, Jr. ${ }^{\text {b }}$, Albert E. Chu d, \\ Peter D. Dehart ${ }^{a}$ and Irwin J. Goldstein ${ }^{\circ}$ \\ "Division of Pulmonary and Critical Care Medicine, Department of Internal Medicine, " Department of Pathology. \\ "Department of Biological Chemistry, University of Michigan, Ann Arbor, MI 48109, and ${ }^{d} E-Y$ Laboratories, Inc., \\ San Mateo, CA 94401 (U.S.A.)
}

(Received July 8th, 1985)

Key words: $\alpha$-D-Galactopyranosyl group; Laminin; Phosphatidylcholine; Lectin binding; (Type II cell)

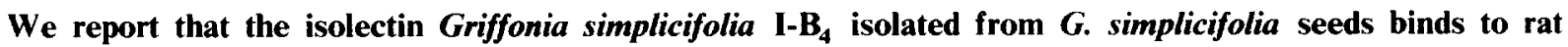
alveolar macrophages present in frozen sections of lung tissue or bronchoalveolar lavage fluid. $G$. simplicifolia I-B $\mathrm{B}_{4}$ does not bind to alveolar epithelial cells. We established that $G$. simplicifolia I-B $\mathrm{B}_{4}$ binds to the macrophages via interaction with terminal $\alpha$-D-galactopyranosyl residues present on these cells. This was substantiated by demonstrating that binding is inhibited either by the haptenic sugar $\alpha$-D-galactopyranoside or by treating the cells with coffee bean $\alpha$-galactosidase. Because murine laminin is known to contain terminal $\alpha$-D-galactopyranosyl end-groups, and because we found that an anti-laminin antiserum binds to rat alveolar macrophages, we suspect that $G$. simplicifolia $I-B_{4}$ may be binding to laminin present on the macrophages. To isolate alveolar type II epithelial cells from rat lungs, we developed a method that utilizes the lectin $G$. simplicifolia $I$. When proteinase-derived suspensions of pulmonary cells are incubated with $G$. simplicifolia I, the macrophages agglutinate and can be removed by filtration through nylon mesh. After incubating the resulting cellular suspension in tissue culture, the adherent cells are $94 \pm 2 \%$ (S.D.) type II cells. When compared to cells isolated by repeated differential adherence, the lectin-prepared type II cells have similar morphology and staining characteristics, form domes in monolayers and incorporate similar amounts of palmitate into disaturated phosphatidylcholine. We believe that the procedure outlined in this report provides a simple and effective method to isolate type II alveolar epithelial cells from rat lungs.

\section{Introduction}

Recently, there has been an increasing awareness that pulmonary type II alveolar epithelial

\footnotetext{
* To whom correspondence should be addressed at: Division of Pulmonary and Critical Care Medicine, University Hospital, Box 055, 1405 East Ann Street, Ann Arbor, MI 48109, U.S.A.

Abbreviations: $\alpha$-D-Gal $p, \alpha$-D-galactopyranosyl; Me $\alpha$-D-Gal $p$, methyl $\alpha$-D-galactopyranoside; buffer $1,0.15 \mathrm{M} \mathrm{NaCl} / 10 \mathrm{mM}$ sodium phosphate (pH 7.2); Hepes, 4-(2-hydroxyethyl)-1piperazineethanesulfonic acid.
}

cells are very important for maintaining the structural and functional integrity of the lung. For example, it is now known that type II cells: (1) limit the leakage of solute and water into the alveolar air spaces both by serving as a permeability barrier [1] and by utilizing active transport [2,3], (2) are able to replicate and replace the more easily injured type I epithelial cells [4,5], and (3) synthesize and secrete the alveolar lining fluid surfactant $[6,7]$.

Investigation of type II cells has been greatly assisted by the development of methods to isolate 
and maintain the cells in primary tissue culture. The procedures currently used to obtain type II cells utilize proteinases to release the cells from the alveolar surface [8-12]. To isolate the type II cells from the cellular suspension, density gradient centrifugation $[8-10,12]$, centrifugal elutriation [13], differential adherence [11], or fluorescenceactivated cell sorting [14] have been used.

Although these techniques provide type II cells for study, each has its problems. We find that the percentage of type II cells obtained by the differential adherence method is less than $80 \%$ if the lungs are digested with proteinases long enough to release a substantial number of cells. Discontinuous density gradient centrifugation affords type II cells of greater than $80 \%$ purity; however, only a subset of the density distribution of type II cells is isolated.

In order to develop a simpler method to isolate type II cells, we made use of an observation that we made while studying the properties of rat lung cells. In particular, we noted that alveolar macrophages were agglutinated by a lectin (Griffonia simplicifolia I) isolated from the seeds of G. simplicifolia. This lectin, which has a specificity for $\alpha$-D-galactopyranosyl ( $\alpha$-D-Gal $p$ ) and $N$-acetyl$\alpha$-galactosaminyl end-groups [15-17], was shown to bind to thioglycolate-stimulated, but not resident murine peritoneal macrophages $[18,19]$. In this report, we characterize the binding of $G$. simplicifolia I to alveolar macrophages and present a simplified procedure that can be utilized to isolate type II alveolar epithelial cells.

\section{Materials and Methods}

Animals. Specific pathogen-free, male, Fischer344 rats weighing $200-300 \mathrm{~g}$ were obtained from Charles River Breeders (Portage, MI).

Lectins. G. simplicifolia I was isolated and purified by the method of Hayes and Goldstein [15]. G. simplicifolia I was also obtained from $\mathrm{E} \cdot \mathrm{Y}$ Laboratories (San Mateo, CA) who utilize the same purification technique. The isolectin G. simplicifolia $\mathrm{I}_{-} \mathrm{B}_{4}$ was prepared by the method of Delmotte and Goldstein [20]. G. simplicifolia I-B was biotinylated by suspending $2 \mathrm{mg}$ in $1 \mathrm{ml} 0.15$ $\mathrm{M} \mathrm{NaCl} / 10 \mathrm{mM}$ sodium phosphate buffer $(\mathrm{pH}$ 7.2) (buffer 1) and adding $70 \mathrm{mg}$ of biotinyl- $N$-hy- droxysuccinimide ester. The mixture was incubated at room temperature for $2 \mathrm{~h}$ or until a precipitate began to form. The solution was then dialyzed four times against 1 liter of buffer 1 at $4^{\circ} \mathrm{C}$. Any precipitate was removed by centrifugation.

Enzymes Trypsin (type III), porcine pancreatic elastase (type I), deoxyribonuclease I (type III), $\alpha$-galactosidase (green coffee bean) were obtained from Sigma (St. Louis, MO).

Miscellaneous. Ketamine was obtained from Parke-Davis (Morris Plains, NJ); Dulbecco's modified Eagle's media, Hanks' balanced salt solution lacking calcium and magnesium, fetal bovine serum, penicillin, streptomycin and amphotericin B from Gibco (Grand Island, NY); sodium palmitate, methyl- $\alpha$-D-galactopyranoside (Me $\alpha$-DGal $p$ ), soybean trypsin inhibitor (type II-S), bovine serum albumin (A6003) and Hepes from Sigma (St. Louis, MO); phosphine dye (C.I. 46045) from Polysciences (Warrington, PA); [9,10(n)$\left.{ }^{3} \mathrm{H}\right]$ palmitic acid and di[1- $\left.{ }^{14} \mathrm{C}\right]$ palmitoylphosphatidylcholine from New England Nuclear (Boston, MA)

Type II cell isolation procedure. Sterile instruments and solutions were used throughout the procedure. Penicillin base $100000 \mathrm{U} / 1$, streptomycin base $100 \mathrm{mg} / \mathrm{l}$, and amphotericin B 250 $\mu \mathrm{g} / 1$ were added to the Dulbecco's modified Eagle's media to suppress microbial growth. Following the intraperitoneal injection of ketamine $(0.1$ $\mathrm{mg} / \mathrm{kg}$ body weight) for anesthesia, a blunt $16-$ gauge needle was inserted into the trachea through a neck incision. The abdomen was opened and the animal exsanguinated by severing a major vessel. The chest was then opened and the anterior rib cage and thymus removed. The lungs were perfused with $40 \mathrm{ml}$ of Hanks' balanced salt solution lacking calcium and magnesium at $4^{\circ} \mathrm{C}$ under 30 $\mathrm{cm}$ water pressure through a cannula placed in the main pulmonary artery via an incision in the right ventricle. Another incision was made in the left atrial appendage to provide an exit for the perfusate. To deaerate the alveoli, the lungs with heart and mediastinal structures intact were suspended in a vacuum flask in such a way that the tracheal lumen was open to the interior of the container. A vacuum was applied for $90 \mathrm{~s}$ and then gradually released. 
To reduce the number of alveolar macrophages, the lungs were lavaged with $50 \mathrm{ml}$ of iced Hanks' balanced salt solution lacking calcium and magnesium in $8-10-\mathrm{ml}$ aliquots. Each aliquot was instilled and aspirated from the lungs three times. Next the lungs were distended with $10-12 \mathrm{ml}$ of a proteinase solution containing $12.6 \mathrm{U} / \mathrm{ml}$ porcine pancreatic elastase, $25 \mu \mathrm{g} / \mathrm{ml}$ trypsin and $20 \mathrm{mM}$ Hepes in Dulbecco's modified Eagle's media (pH 7.4). The lungs were submerged in normal saline at $37^{\circ} \mathrm{C}$ and incubated for $20 \mathrm{~min}$. Every $5 \mathrm{~min}$, the lungs were redistended to total lung capacity with fresh proteinase solution.

To halt the digestion and to degrade any denatured DNA which might increase the viscosity of the solution, the lungs were distended with $10 \mathrm{ml}$ of an iced solution containing $0.5 \mathrm{mg} / \mathrm{ml}$ soybean trypsin inhibitor, $10 \%$ fetal bovine serum and 60 $\mu \mathrm{g} / \mathrm{ml}$ deoxyribonuclease $\mathrm{I}$ in Dulbecco's modified Eagle's media ( $\mathrm{pH} 7.2$ ). The lungs were then dissected free of the mediastinal structures and minced into $1-\mathrm{mm}^{3}$ sections using a Mcllwain tissue chopper (Brinkman Instruments, Westbury, NY). The tissue pieces and any fluid that drained from the lungs during mincing were transferred to a trypsinizing flask containing $30 \mathrm{ml}$ of the same anti-proteinase/nuclease solution and stirred on ice for $10 \mathrm{~min}$. The suspension was then passed through $100 \mu \mathrm{m}$ nylon mesh (Tetko, Elmsford, NY).

The cells in suspension were pelleted at $75 \mathrm{~g}$ for $10 \mathrm{~min}$ at $4^{\circ} \mathrm{C}$, washed once in Hanks' balanced salt solution lacking calcium and magnesium, and then resuspended in $4 \mathrm{ml}$ of the same buffer containing $0.1 \mathrm{mg} / \mathrm{ml}$ bovine serum albumin. To this was added $0.2 \mathrm{ml}$ of a $1 \mathrm{mg} / \mathrm{ml}$ solution of lectin. Rather than using the more expensive $G$. simplicifolia $\mathrm{I}_{-} \mathrm{B}_{4}$, we employed unfractionated $G$. simplicifolia I. G. simplicifolia I consists of a mixture of five isolectins. Each isolectin is a tetramer made up of a combination of two distinct subunits (A and B). The A-chain binds to both $N$-acetyl- $\alpha$ galactosaminyl and $\alpha$-D-Gal $p$ end-groups, while the B-chain is specific for $\alpha$-D-Gal $p$ units $[16,17]$. When added to cells that have terminal $\alpha$-D-Gal $p$ groups on their surface, $G$. simplicifolia I agglutinates the cells [21].

The cellular suspension containing $G$. simplicifolia I lectin was incubated at $37^{\circ} \mathrm{C}$ for $30 \mathrm{~min}$ in a
$5 \mathrm{ml}$ polypropylene tube. The tube was gently inverted several times every $5 \mathrm{~min}$ to insure adequate mixing. To remove the cellular aggregates which formed during incubation, the suspension was sequentially filtered through 37 and $15 \mu \mathrm{m}$ nylon mesh. The single-cell suspension was then centrifuged at $75 \times g$ for 10 min at room temperature and resuspended in Dulbecco's modified Eagle's media containing $10 \%$ fetal bovine serum. The cells were then placed into plastic tissue culture dishes (Corning Glass Works, Corning, NY) and incubated at $37^{\circ} \mathrm{C}$ in a $5 \% \mathrm{CO}_{2} /$ air atmosphere.

For comparison, type II cells were purified by repeated differential adherence. In particular, the proteinase-derived cellular suspension was filtered through 100,37 and $15 \mu \mathrm{m}$ nylon mesh. The cells were washed and resuspended in Dulbecco's modified Eagle's media containing $10 \%$ fetal bovine serum and incubated at $37^{\circ} \mathrm{C}$ in $5 \% \quad \mathrm{CO}_{2} /$ air. After $3 \mathrm{~h}$, the nonadherent cells were transferred to a new culture dish and allowed to incubate overnight. When these cells were released by trypsinization, $55-75 \%$ were type II cells by phosphine-staining criteria. If the cells were again placed in tissue culture dishes and incubated for $22 \mathrm{~h}$, greater than $85 \%$ of the adherent cells were type II.

Morphology. Lung tissue was obtained for histological analysis from rats deeply anesthetized with ketamine. The trachea was cannulated and the lungs distended to total lung capacity with O.C.T. compound (Miles Laboratories, Naperville, IL) to embed the tissue. Pieces of peripheral lung were excised and frozen in liquid nitrogen. Thin sections were cut using an IEC CTD-1 cryostat (International Equipment, Needham Heights, MA).

Cells in suspension were sedimented onto glass slides coated with poly-L-lysine ( $350 \mathrm{kDa}$, Sigma) using a cytocentrifuge (Shandon, Astmoor, U.K.) and then air-dried. The cells were stained using a modification of the Papanicolaou procedure [8] and by methods that detect esterase activity using naphthol AS-D chloroacetate [22] or $\alpha$-naphthyl acetate (90-A1 kit, Sigma, St. Louis, MO) as substrate. Cell suspensions were also examined with a fluorescence microscope after staining with phosphine dye [23].

To prepare cells for transmission electron mi- 
croscopy, the cells were fixed in $2.5 \%$ glutaraldehyde and post-fixed with $1 \%$ osmium tetroxide. After en bloc fixation with uranyl acetate, the cells were dehydrated with ethanol and propylene oxide. The cells were imbedded in Araldite-Poly/Bed 812 and thin sections were stained with lead citrate and uranyl acetate.

Biotinylated lectin-staining reactions. The ability of cells to bind lectin was determined by the biotin-avidin-peroxidase technique using biotinylated $G$. simplicifolia $\mathrm{I}_{-} \mathrm{B}_{4}$. Cytospin preparations were air-dried, fixed in acetone, and stored at $-20^{\circ} \mathrm{C}$ until use. Slides were always used within $48 \mathrm{~h}$. Upon use, the cells were preincubated with $3 \%$ hydrogen peroxide in methanol to remove any endogenous peroxidase activity. The slides were rehydrated in buffer 1 for $10 \mathrm{~min}$, then incubated with $200 \mu \mathrm{l}$ biotinylated $G$. simplicifolia ${\mathrm{I}-\mathrm{B}_{4}}_{4}$ at 40 $\mu \mathrm{g} / \mathrm{ml}$ in buffer 1 ( $\mathrm{pH}$ 7.2). Controls consisted of incubating the cells with buffer 1 alone or with 25 $\mathrm{mM}$ Me $\alpha$-D-Gal $p$ added to the lectin/buffer 1 solution. Following the first incubation ( $30 \mathrm{~min}$ at $25^{\circ} \mathrm{C}$ ) the slides were washed three times with buffer 1 . The slides were then incubated for 30 min at $25^{\circ} \mathrm{C}$ with $200 \mu 1$ of an avidin-biotin-peroxidase complex reagent in Buffer 1 . The slides were subsequently washed three times with buffer 1 and incubated for $10 \mathrm{~min}$ with diaminobenzidine ( $1 \mathrm{mg} / \mathrm{ml}$ ) and $0.006 \% \mathrm{H}_{2} \mathrm{O}_{2}$. The slides were washed twice with distilled water and counterstained with hematoxylin for $1 \mathrm{~min}$. Finally, the slides were rinsed in tap water for $5 \mathrm{~min}$ and mounted with coverslips using an aqueous mounting medium.

$\alpha$-Galactosidase treatment of alveolar macrophages. The specificity of the binding of biotinylated $G$. simplicifolia $\mathrm{I}-\mathrm{B}_{4}$ was further determined by experiments in which cytospin preparations of alveolar macrophages were pretreated with $\alpha$ galactosidase prior to staining with the $G$. simplicifolia ${\mathrm{I}-\mathrm{B}_{4}}_{4}$ lectin. In these experiments, alveolar macrophages affixed to glass slides as cytospin preparations were air-dried, fixed in acetone and used immediately. Coffee bean $\alpha$-galactosidase was diluted to $1.2 \mathrm{U} / \mathrm{ml}$ in buffer $1(\mathrm{pH} \mathrm{6.0)}$. The cytospin preparations were washed twice in buffer 1 ( $\mathrm{pH} \mathrm{6.0)}$, then incubated at room temperature for $45 \mathrm{~min}$ with the $\alpha$-galactosidase solution. Controls consisted of incubating cytospin preparations in buffer 1 (pH 6.0) without enzyme, and in $\alpha$ galactosidase diluted in buffer $1(\mathrm{pH} 7.2)-\mathrm{a} \mathrm{pH}$ at which the enzyme is inactive. Following this incubation the cells were washed three times with buffer 1 ( $\mathrm{pH} \mathrm{7.2),} \mathrm{then} \mathrm{stained} \mathrm{with} \mathrm{the} \mathrm{biotiny-}$ lated $G$. simplicifolia $\mathrm{I}_{-} \mathrm{B}_{4}$ as described above.

Immunoperoxidase staining with anti-laminin antiserum. Rabbit anti-laminin antiserum was prepared in our laboratory by repeated intradermal injections of laminin purified from the EHS murine sarcoma. The antiserum was tested for specificity by ELISA [24], immunodiffusion [25] and immunoblotting [26]. Strong reactivity was found against laminin, whereas no cross-reactivity was found against bovine serum albumin, fibronectin, type IV collagen, a mixture of type I and type II collagen, ovalbumin, or thyroglobulin.

This anti-laminin antiserum and the corresponding prebleed from the same rabbit were used to stain cytospin preparations of alveolar macrophages by immunoperoxidase procedures. A commercial avidin-biotin-peroxidase kit (Vectastain, Vector Labs, Burlingame, CA) was used to accomplish the staining. 30-min incubations at room temperature were used throughout the procedure and diaminobenzidine was used as the chromagen. After staining, the slides were counterstained with hematoxylin, rinsed with tap water and mounted with coverslips using an aqueous mounting medium.

Palmitate incorporation. The rate of incorporation of $\left[{ }^{3} \mathrm{H}\right]$ palmitate into total and disaturated phosphatidylcholine by epithelial cells was measured in the following manner. Type II cells were isolated and plated at $8 \cdot 10^{5}$ cells per well into 24-well tissue culture plates (Falcon, Becton Dickinson, Oxnard, CA). After overnight culture, the cells were loosely adherent, and by the second day, they formed confluent monolayers. The monolayers were washed and then incubated with 5 $u \mathrm{Ci} /$ well of $\left[{ }^{3} \mathrm{H}\right]$ palmitate in Dulbecco's modified Eagle's medium containing a total of $0.1 \mathrm{mM}$ palmitate complexed with $10 \mathrm{mg} / \mathrm{ml}$ of essentially fatty acid-free bovine serum albumin. After $4 \mathrm{~h}$ of incubation at $37^{\circ} \mathrm{C}$ in $5 \% \mathrm{CO}_{2} /$ air, the cells were released with trypsin and the lipid was extracted by the procedure of Folch et al. [27]. Before extraction, $1 \mathrm{mg}$ dog lung lipid and $50000 \mathrm{dpm}$ di $\left[1-{ }^{14} \mathrm{C}\right]$ palmitoylphosphatidylcholine were added 
to serve as a lipid carrier and an internal standard, respectively. The phases were separated using 0.1 $\mathrm{M} \mathrm{K}_{2} \mathrm{CO}_{3}$. The extract was dried under nitrogen and chromatographed on thin-layer silica-gel plates (E.M. Science, Cincinnati, $\mathrm{OH}$ ) using chloroform/ methanol/acetic acid/water, $65: 25: 8: 4$ as the mobile phase. The band that co-migrated with authentic phosphatidylcholine was scraped and the lipid extracted using chloroform/methanol/ water/acetic acid, 50:20:2:1 and chloroform/ methanol/water $30: 60: 5$. The extract was dried, dissolved in scintillation fluid and the radioactivity counted (LS 7500 Liquid Scintillation System, Beckham Instruments, Fullerton, CA). The incorporation of $\left[{ }^{3} \mathrm{H}\right]$ palmitic acid into disaturated phosphatidylcholine was measured by the technique of Mason et al. [28].

\section{Results}

Frozen sections of rat lung were examined to determine which cells had terminal $\alpha$-D-Gal $p$ residues recognized by the $G$. simplicifolia $\mathbf{I}-\mathrm{B}_{4}$ isolectin. Using the biotin-avidin-peroxidase technique, we noted that alveolar macrophages were stained by the biotinylated $G$. simplicifolia $\mathrm{I}^{-\mathrm{B}_{4}}$ isolectin. Epithelial cells lining the alveolar air spaces were not stained. If $G$. simplicifolia $\mathrm{I}-\mathrm{B}_{4}$ was omitted during the procedure, no staining of macrophages was seen. To demonstrate that the lectin was binding via its sites for $\alpha-\mathrm{D}-\mathrm{Gal} p$ endgroups, the haptenic sugar Me $\alpha-\mathrm{D}-\mathrm{Gal} p$ was added to the incubation mixture. The presence of $25 \mathrm{mM}$ Me $\alpha$-D-Gal $p$ inhibited macrophage staining.

The binding of $G$. simplicifolia $\mathrm{I}_{-} \mathrm{B}_{4}$ was further studied using alveolar macrophages obtained by bronchoalveolar lavage. Cytocentrifuge-prepared slides of bronchoalveolar lavage cells were stained by the Papanicolaou method and found to consist of over $98 \%$ alveolar macrophages. Histochemical staining for esterase activity to $\alpha$-naphthyl acetate showed that greater than $98 \%$ of the cells were stained. Using the biotin-avidin-peroxidase technique, we found that biotinylated $G$. simplicifolia I- $\mathrm{B}_{4}$ bound to all of the bronchoalveolar lavage macrophages in the cytospin preparations (Fig. $1 \mathrm{a})$. The addition of $\mathrm{Me} \alpha-\mathrm{D}-\mathrm{Gal} p$ to the reaction mixture inhibited the binding (Fig. 1b). To further verify that $G$. simplicifolia $\mathrm{I}-\mathrm{B}_{4}$ was attaching to

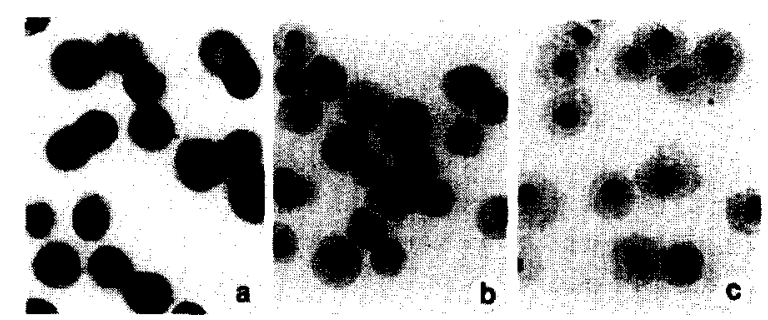

Fig. 1. Photomicrographs of bronchoalveolar lavage cells incubated with biotinylated $G$. simplicifolia $\mathrm{I}_{-} \mathrm{B}_{4}$ and developed by the biotin-avidin-peroxidase technique. (a), (b) and (c) were treated identically except that (b) was exposed to lectin in the presence of $25 \mathrm{mM} \mathrm{Me} \alpha$-D-Gal $p$ and (c) was previously treated with $\alpha$-galactosidase. The macrophages in (a) are intensely stained (brown) indicating the presence of bound $G$. simplicifolia $\mathrm{I}-\mathrm{B}_{4}$. The macrophages in (b) and (c) are not stained by the lectin. (Original $470 \times$.)

the macrophages via $\alpha$-D-Gal $p$ end-groups located on the cellular surface, we removed these residues by treatment with coffee bean $\alpha$-galactosidase. If macrophages were treated with $\alpha$-galactosidase using a $\mathrm{pH}$ at which the enzyme is active ( $\mathrm{pH} \mathrm{6.0)}$, G. simplicifolia $\mathrm{I}-\mathrm{B}_{4}$ no longer bound to the cells (Fig. 1c). Exposure to $\mathrm{pH} 6.0$ buffer alone did not inhibit lectin binding. At $\mathrm{pH}$ 7.2, where the $\alpha$-galactosidase is no longer active, the macrophages retained their ability to bind $G$. simplicifolia $\mathrm{I}-\mathrm{B}_{\mathbf{4}}$.

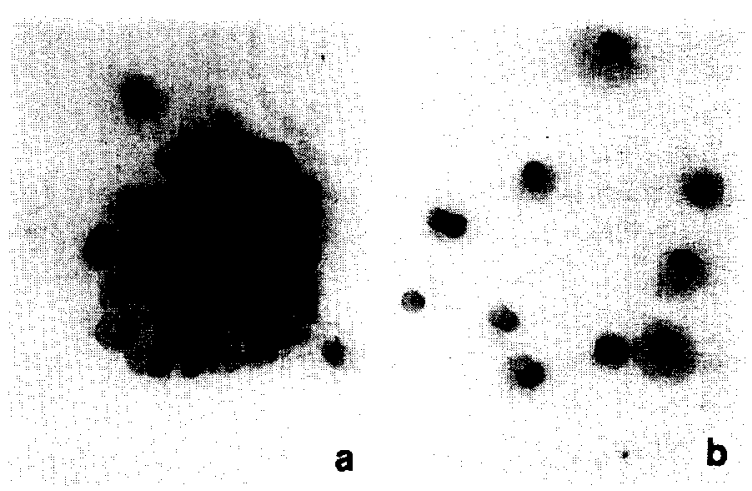

Fig. 2. Photomicrographs of bronchoalveolar lavage cells. Washed cells were suspended in Hanks' balanced salt solution lacking calcium and magnesium containing $1 \mathrm{mg} / \mathrm{ml}$ bovine serum albumin and $50 \mu \mathrm{g} / \mathrm{ml} \mathrm{G}$. simplicifolia I and incubated for $30 \mathrm{~min}$ at $37^{\circ} \mathrm{C}$. Cytocentrifuge slides were prepared and the cells dried and stained by the Papanicolaou technique. (a) and (b) were treated identically except that $25 \mathrm{mM} \mathrm{Me} \alpha-\mathrm{D}-\mathrm{Gal} p$ was added to (b). (Original $470 \times$.) 


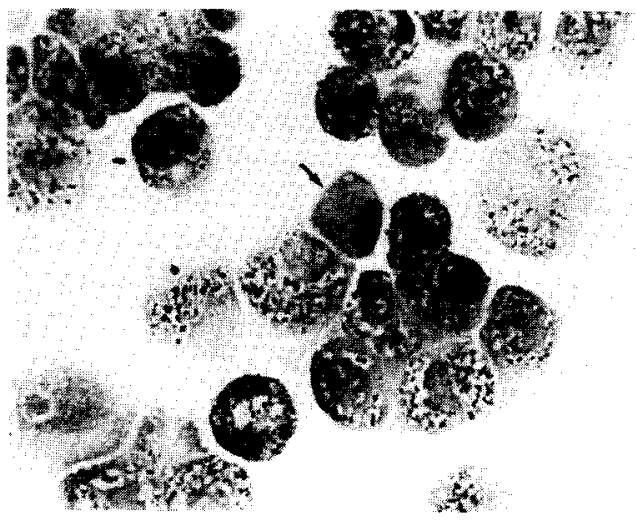

Fig. 3. Photomicrograph of lectin-prepared type II alveolar epithelial cells. Following 2 days in culture, cells were trypsinized and sedimented onto glass slides using a cytocentrifuge. The air-dried slides were stained by a modification of the Papanicolaou method [8]. The type II cells contain characteristic deep-blue granules, each surrounded by a clear halo. The cell marked with an arrow is not a type II cell. (Original $\times 1175$.)

The identity of the macrophage surface glycoconjugate to which $G$. simplicifolia $\mathrm{I}-\mathrm{B}_{4}$ binds is not known. Because murine laminin possesses $\alpha$ D-Gal $p$ end-groups [29], one possibility is that the $\alpha$-D-Gal $p$ structures present on rat alveolar macrophages are due to laminin. To investigate this, we stained alveolar macrophages with rabbit antilaminin antiserum. Using the biotin-avidin-peroxidase technique, we found that anti-laminin antibody bound to the alveolar macrophages.

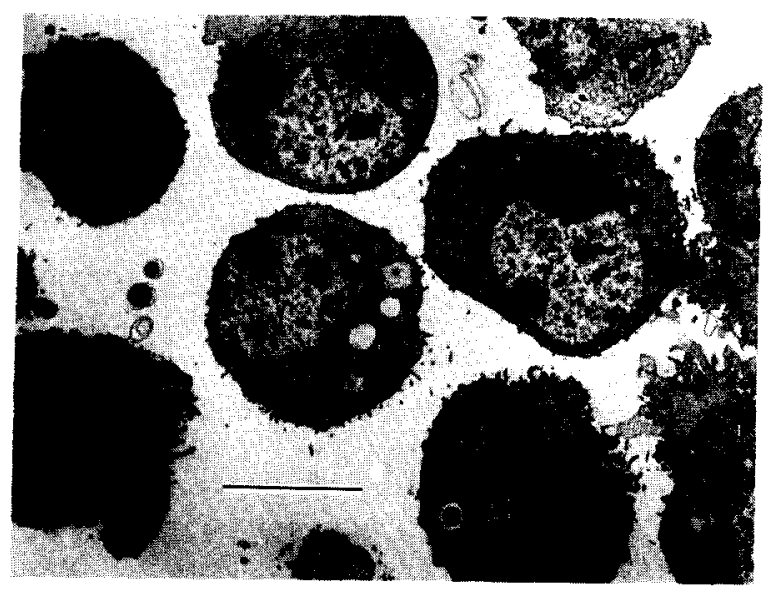

Fig. 4. Transmission electron micrograph of lectin-prepared type II alveolar epithelial cells that have been released from the culture dish by trypsinization. (Bar $=5 \mu \mathrm{m}$.)

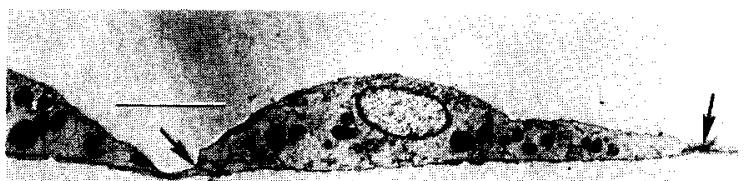

Fig. 5. Transmission electron micrograph of lectin-prepared type II alveolar epithelial cells that have been fixed with glutaraldehyde prior to removal from the culture dish. Adjacent cells are jointed by tight junctions (arrows). (Bar $=$ to $5 \mu \mathrm{m}$.)

Macrophages exposed to pre-immune serum showed no staining by the peroxidase product.

We found that rat alveolar macrophages agglutinated when incubated with $50 \mu \mathrm{g} / \mathrm{ml} \mathrm{G}$. simplicifolia I in Hanks' balanced salt solution lacking calcium and magnesium for $30 \mathrm{~min}$ (Fig. 2a). The agglutination was inhibited when $25 \mathrm{mM}$ Me $\alpha$-DGal $p$ was added to the incubation mixture (Fig. $2 b$ ). The ability of $G$. simplicifolia I lectin to agglutinate alveolar macrophages provided a method to remove the macrophages from suspensions of type II epithelial cells. Using the procedure outlined in Materials and Methods, the crude cellular suspension obtained from the lungs of a single rat by proteinase digestion contained $(4.9 \pm$ 1.7) (S.D., $n=10) \cdot 10^{7}$ cells, $48 \pm 11 \%$ of which were type II cells by phosphine dye staining criteria. After incubating the cellular suspension

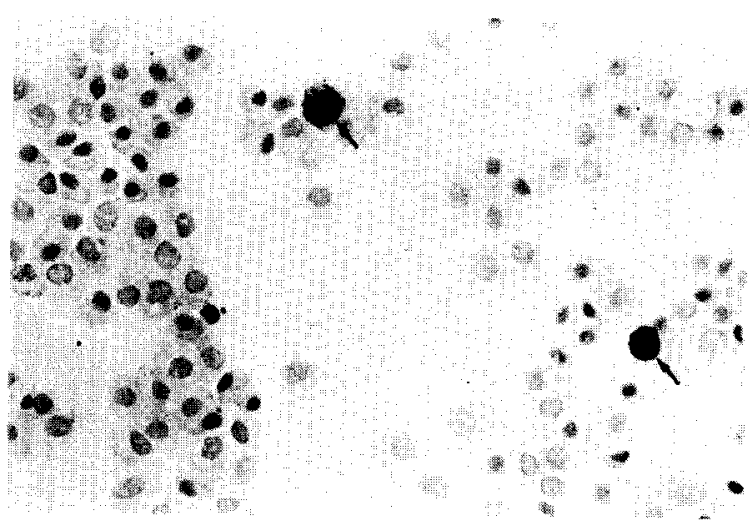

Fig. 6. Photomicrograph of lectin-prepared type II alveolar epithelial cells as in Fig. 3. The cytocentrifuged cells were incubated with biotinylated $G$. simplicifolia $\mathrm{I}_{-} \mathrm{B}_{\mathbf{4}}$ and stained by the biotin-avidin-peroxidase technique. The cell population depicted in this figure contains two cells (arrows) which stain with G. simplicifolia $\mathrm{I}_{-} \mathrm{B}_{4}$ indicating the presence of a few residual cells that process $\alpha$-D-Gal $p$ end-groups. $(\times 470$.) 
with $50 \mu \mathrm{g} / \mathrm{ml}$ of $G$. simplicifolia $\mathrm{I}$ for $30 \mathrm{~min}$ and removing the agglutinated cells by filtration through nylon mesh, the suspension contained (1.2 $\pm 0.5) \cdot 10^{7}$ cells per rat, $77 \pm 11 \%$ of which were identified as type II cells by phosphine staining criteria.

After overnight incubation at $37^{\circ} \mathrm{C}$ in a $5 \%$ $\mathrm{CO}_{2} /$ air atmosphere, type II cells adhered loosely to the culture dish, and after $48 \mathrm{~h}$ they formed confluent monolayers. The time for adherence and formation of monolayers was the same as has been reported previously $[30,31]$. The plating efficiency of the type II cells was $34.3 \pm 8.7 \%$ (S.D., $n=6$ ). Contaminating or dead cells did not adhere. When confluent monolayers of cells were released from the culture dish by trypsinization, $94 \pm 2 \%$ (S.D.) of the adherent cells were type II by phosphine and modified Papanicolaou staining (Fig. 3). Fig. 4 is a representative transmission electron micrograph of the cells that were released from the culture dish by trypsination. Lamellar inclusion bodies and surface microvilli are evident. If the cells were fixed with glutaraldehyde before being scraped from the plate with a rubber policeman, intercellular tight junctions are identifiable (Fig.

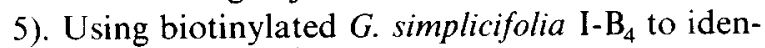
tify macrophages, we found that fewer than $2 \%$ of the cells were stained by the lectin (Fig. 6). To use another technique to detect residual macrophages, we examined the cells for the presence of esterase

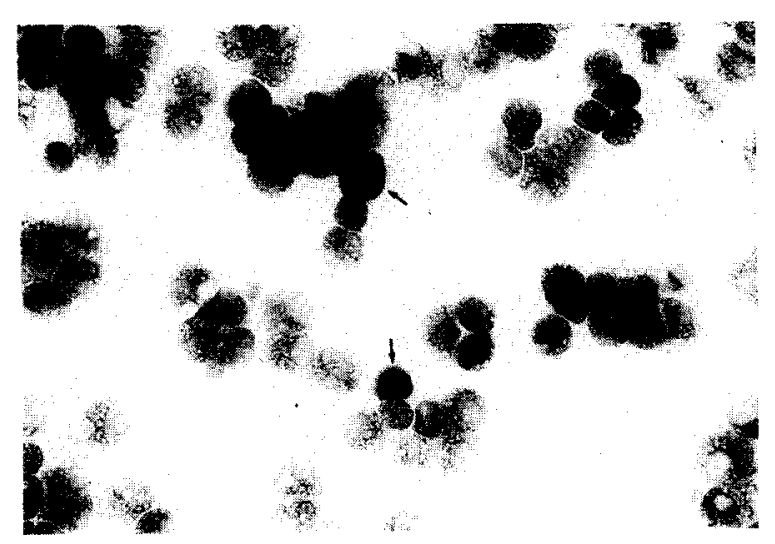

Fig. 7. Photomicrograph of lectin-prepared type II alveolar epithelial cells as in Fig. 3. The cells were stained by a technique to detect esterase activity to naphthol AS-D chloroacetate [22]. Two of the cells in the figure (arrows) stain with a reddish color, indicating esterase activity. $(\times 470$.) activity to naphthol AS-D chloroacetate. We noted that alveolar macrophages that had been maintained in culture for 2 days demonstrated esterase activity to this substrate. (No detectable esterase activity was present on alveolar macrophages that had been stained immediately after being isolated from lavage fluid.) When lectin-isolated epithelial cells were stained for the presence of esterase, less than $3 \%$ of the cells were positive (Fig. 7).

The use of $G$. simplicifolia I in the isolation procedure does not appear to harm or alter the type II cells. The adherent cells were greater than 95\% viable by Trypan blue exclusion criterion. Confluent monolayers of the epithelial cells formed 'domes' indicating the presence of transcellular active transport [2,3]. Because cultured type II cells are known to take up and incorporate palmitate into phosphatidylcholine [7], we compared these properties in lectin-isolated cells with those of cells purified by differential adherence. If one assumes that the specific activity of $\left[{ }^{3} \mathrm{H}\right]$ palmitic acid in newly synthesized phosphatidylcholine is the same as that in the media, then in $4 \mathrm{~h}, 10^{6}$ lectin-prepared cells incorporated $9.4 \pm 1.3$ (S.E.) nmol palmitic acid into total phosphatidylcholine and $4.4 \pm 0.5 \mathrm{nmol}$ into disaturated phosphatidylcholine. Type II cells prepared by differential adherence without lectin treatment incorporated 6.8 $\pm 0.4 \mathrm{nmol}$ into total phosphatidylcholine and 3.2 $\pm 0.2 \mathrm{nmol}$ into disaturated phosphatidylcholine.

\section{Discussion}

In this study, we demonstrated that $G$. simplicifolia $\mathrm{I}-\mathrm{B}_{4}$ binds to alveolar macrophages obtained from the lungs of specific pathogen-free rats. Because the binding is inhibited by the haptenic sugar Me $\alpha-\mathrm{D}-\mathrm{Gal} p$ or by treatment of the cells with $\alpha$-galactosidase, we conclude that $G$. simplicifolia $\mathrm{I}_{-} \mathrm{B}_{4}$ binds to the macrophages via its binding sites for terminal $\alpha$-D-Gal $p$ groups. Previous studies have demonstrated that $G$. simplicifolia $\mathrm{I}_{-} \mathrm{B}_{4}$ binds to murine peritoneal macrophages via $\alpha-D_{-}$ Gal $p$ units and that this binding is dependent upon the state of differentiation of the macrophages $[18,19]$. In particular, resident peritoneal macrophages do not bind the isolectin while those elicited by thioglycollate do. Our finding of terminal $\alpha$-D-Gal $p$ units on alveolar macrophages may 
be relevant to understanding the state of activation or differentiation of alveolar macrophages.

Using an anti-laminin antibody, we detected laminin associated with the bronchoalveolar lavage macrophages. Because laminin is known to possess $\alpha$-D-Gal $p$ end-groups [29], we speculate that $G$. simplicifolia $\mathrm{I}-\mathrm{B}_{4}$ may be binding to macrophageassociated laminin. The presence of laminin is of interest in that this glycoprotein is believed to be involved in the interaction of cells both with their surrounding connective tissue and possibly with each other. Wicha and Huard [19] have also found that the presence of laminin is correlated with the degree of macrophage differentiation. In particular, they have shown that $14 \%$ of resident murine peritoneal macrophages bind anti-laminin antibody and that this percent increases to $60 \%$ for thioglycollate-elicited cells.

In a recent study, Williams [32] described the uptake and intracellular transport of the ferritinlabeled Maclura pomifera lectin into alveolar type II cells. Although the lectin bound to the apical plasma membrane of the type II cells and its binding was inhibited by Me $\alpha-\mathrm{D}-\mathrm{Gal} p$, this is not conclusive evidence for the presence of $\alpha$-D-Gal $p$ end-groups on the surface of these cells. Unlike the G. simplicifolia $\mathrm{I}-\mathrm{B}_{4}$ isolectin, the Maclura pomifera lectin is not specific for $\alpha-\mathrm{D}-\mathrm{Gal} p$ groups. In fact, the extensive study by Sarkar et al. [33] clearly indicates that the lectin's binding site is complementary to $N$-acetyl- $\alpha$-galactosaminyl residues which may be substituted at the C-3 hydroxyl group by $\beta$-D-galactosyl units (i.e., $\operatorname{Gal}(\beta 1,3) \mathrm{GalNAc})$. The critical test for the presence of $\alpha$-D-Gal $p$ end-groups involves treatment of the cells with a purified $\alpha$-D-galactosidase. We have carried out such controls on the bronchoalveolar lavage macrophages and, as indicated above, the macrophages no longer bind the biotinylated G. simplicifolia ${\mathrm{I}-\mathrm{B}_{4}}_{4}$ isolectin. Untreated alveolar epithelial cells do not bind the $\alpha$-D-Gal $p$-specific G. simplicifolia $\mathrm{I}-\mathrm{B}_{4}$ isolectin.

Lectins have previously been utilized for the separation of cells. In 1976, Reisner et al. demonstrated that soybean agglutinin could be used to separate mouse T and B lymphocytes [34], and peanut agglutinin could separate mouse thymocytes into two subpopulations [35]. These studies together with more recent reports utilize the ability of specific lectins to selectively agglutinate a particular cell type within a heterogenous suspension of cells. In the present study, we developed a procedure using the lectin $G$. simplicifolia I to agglutinate and remove contaminating alveolar macrophages from preparations of alveolar epithelial cells.

Our method of preparing pulmonary type II epithelial cells has several inherent advantages. First, there is no need to induce the alveolar macrophages to phagocytize dense particles because the isolation procedure does not depend upon a density centrifugation step. The ability to isolate cells without using differential density centrifugation has an additional benefit. It has been demonstrated that the density distribution of the population of type II cells derived by proteinase digestion of the lung is broad [8,9]. In order to isolate type II cells free from contaminating cells, discontinuous density layers have been selected that effectively exclude the heavier macrophages. Unfortunately, because of the overlap between the density distributions of type II cells and macrophages, a subpopulation of heavier type II cells must be discarded due to macrophage contamination. The subset of type II cells that are systematically excluded because of high density may represent as many as $40 \%$ of the total type II cell population [9]. The methodological problems caused by the use of discontinuous density gradients has been discussed by Pretlow et al. [36]. Because the isolation procedure presented in this paper depends only on the fact that macrophages have $\alpha-D-G a l p$ on their surface and type II cells do not, no subpopulation of type II cells is systematically excluded.

The purity of the type II cells produced by our lectin technique is routinely greater than $90 \%$. We have not been able to achieve this high a yield using the differential adherence technique except when the initial proteinase digestion of the lung is brief. If, however, the incubation with proteinases is allowed to proceed long enough to release an appreciable number of cells from the alveolar surface, the final purity is usually less than $80 \%$.

Type II cells isolated by the lectin procedure and grown in monolayers are greater than 95\% viable. The monolayers form 'domes' indicating that transcellular active transport is intact. The 
cells incorporate $\left[{ }^{3} \mathrm{H}\right]$ palmitate into total and disaturated phosphatidylcholine at a rate similar to cells prepared by differential adherence. Based on these results, we believe that the procedure described in this paper offers an attractive technique to isolate viable pulmonary type II alveolar epithelial cells for study.

\section{Acknowledgements}

We thank Dr. Peter A. Ward for use of laboratory space and access to scientific equipment, William Schade and Glen Merz for excellent technical assistance, and Dr. Theodore F. Beals, Department of Pathology, for performing the electron microscopy. This research was supported in parts by grants from the National Heart Lung Blood Institute (HL31963), National Cancer Institute (CA20424) and the National Institutes of Health (GM29470), and by a grant-in-aid from the American Heart Association with funds contributed in part by the American Heart Association of Michigan (84-1058).

\section{References}

1 Schneeberger, E.E. and Karnovsky, M.J. (1976) Circ. Res. $38,404-411$

2 Goodman, B.E. and Crandall, E.D. (1982) Am. J. Physiol. 243, C96-100

3 Mason, R.J., Williams, M.C. and Widdicombe, J.H. (1983) Am. Rev. Respir. Dis. 127 (Suppl.), S24-28

4 Evans, M.J., Cabral, L.J., Stephens, R.J. and Freeman, G. (1975) Exp. Mol. Pathol. 22, 142-150

5 Adamson, I.Y.R. and Bowden, D.H. (1974) Lab. Invest. 30 , $35-42$

6 Goerke, J. (1974) Biochim. Biophys. Acta 344, 241-261

7 Kikkawa, Y., Yoneda, K., Smith, F., Packard, B. and Suzuki, K. (1975) Lab. Invest. 32, 295-302

8 Kikkawa, Y. and Yoneda, K. (1974) Lab. Invest. 30, 76-84

9 Mason, R.J., Williams, M.C., Greenleaf, R.D. and Clements, J.A. (1977) Am. Rev. Respir. Dis. 115, 1015-1026

10 Dobbs, L.G., Geppert, E.F., Williams, M.C., Greenleaf, R.D. and Mason, R.J. (1980) Biochim. Biophys. Acta 618, 510-523

11 Fisher, A.B., Furia, L. and Berman, H. (1980) J. Appl. Physiol. 49, 743-750
12 Finkelstein, J.N. and Shapiro, D.L. (1982) Lung 160, 85-98

13 Greenleaf, R.D., Mason, R.J. and Williams, M.C. (1979) In Vitro 15, 673-684

14 Leary, J.F., Finkelstein, J.N., Notter, R.H. and Shapiro, D.L. (1982) Am. Rev. Respir. Dis. 125, 326-330

15 Hayes, C.E. and Goldstein, I.J. (1974) J. Biol. Chem. 249. $1904-1914$

16 Murphy, L.A. and Goldstein, I.J. (1977) J. Biol. Chem. 252, 4739-4742

17 Murphy, L.A. and Goldstein, I.J. (1979) Biochemistry 18 4999-5005

18 Maddox, D.E., Shibata, S. and Goldstein. I.J. (1982) Proc. Natl. Acad. Sci. USA 79, 166-170

19 Wicha, M.S. and Huard, T.K. (1983) Exp. Cell Res. 143. 475-479

20 Delmotte, F.M. and Goldstein, 1.J. (1980) Eur. J. Biochem. $112,219-223$

21 Eckhardt, A.E. and Goldstein, I.J. (1983) Biochemistry 22 5280-5289

22 Leder, L.D. (1964) Klin. Wschr. 42, 553

23 Mason. R.J. and Williams, M.C. (1976) Am. Rev. Respir. Dis. 113, 47 (abstr.)

24 Varani, J., Lovett, E.J., III. McCoy, J.P., Jr., Shibata, S., Maddox, D.E., Goldstein, I.J. and Wicha, M. (1983) Am. J. Pathol. 111, 27-34

25 Ouchterlony, O. and Nilsson, L.A. (1978) in Handbook of Experimental Immunology, Vol. 1 (Wier, D.M., ed.). p. 19.1, Blackwell Scientific, Oxford

26 Towbin, H., Staehelin, T. and Gordon. J. (1979) Proc. Natl. Acad. Sci. USA 76, 4350-4354

27 Folch, J., Lees, M. and Sloane Stanley, G.H. (1957) J. Biol. Chem. 226, 497-509

28 Mason, R.J., Nellenbogen, J. and Clements, J.A. (1976) J. Lipid Res. 17, 281-284

29 Shibata, S., Peters, B,, Roberts, D., Goldstein, I.J. and Liotta, L.A. (1982) FEBS Lett. 142, 194

30 Diglio, C.A. and Kikkawa, Y. (1977) Lab. Invest. 37. $622-633$

31 Mason, R.J., Williams, M.C., Widicombe, J.H., Sanders, M.J., Misfeldt, D.S. and Berry, L.C. Jr. (1982) Proc. Natl. Acad. Sci. USA 79, 6033-6037

32 Williams, M.C. (1984) Proc. Natl. Acad. Sci. USA 81 . 6383-6387

33 Sarkar, M., Wu, A.M. and Kabat. E.A. (1981) Arch. Biochem. Biophys. 209, 204-218

34 Reisner, Y., Ravid, A. and Sharon, N. (1976) Biochem. Biophys. Res. Commun. 72, 1585-1591

35 Reisner, Y., Linker-Israeli, M. and Sharon, N. (1976) Cell Immun. 25, 129-134

36 Pretlow, T.G., III. Weir, E.E., and Zettergren, J.G. (1975) Int. Rev. Exp. Pathol. 14, 91-204 